\title{
GMR
}

\section{Structure and genetic diversity of natural Brazilian pepper populations (Schinus terebinthifolius Raddi)}

\author{
S.V. Álvares-Carvalho' ${ }^{1}$ J.F. Duarte ${ }^{2}$, T.C. Santos ${ }^{3}$, \\ R.M. Santos ${ }^{2}$, R. Silva-Mann ${ }^{1}$ and D. Carvalho ${ }^{2}$ \\ ${ }^{1}$ Laboratório de Recursos Genéticos e Óleos Essenciais, \\ Departamento de Engenharia Agronômica, \\ Universidade Federal de Sergipe, São Cristóvão, SE, Brasil \\ ${ }^{2}$ Departamento de Ciências Florestais, \\ Universidade Federal de Lavras, Lavras, MG, Brasil \\ ${ }^{3}$ Universidade Tiradentes, Farolândia, Aracaju, SE, Brasil \\ Corresponding author: S.V. Alvares-Carvalho \\ E-mail: sheilaalvares@yahoo.com.br / carvalhosva@gmail.com
}

Genet. Mol. Res. 15 (2): gmr.15028123

Received November 24, 2015

Accepted February 26, 2016

Published June 17, 2016

DOI http://dx.doi.org/10.4238/gmr.15028123

\begin{abstract}
In the face of a possible loss of genetic diversity in plants due the environmental changes, actions to ensure the genetic variability are an urgent necessity. The extraction of Brazilian pepper fruits is a cause of concern because it results in the lack of seeds in soil, hindering its distribution in space and time. It is important to address this concern and explore the species, used by riparian communities and agro-factories without considering the need for keeping the seeds for natural seed banks and for species sustainability. The objective of this study was to evaluate the structure and the genetic diversity in natural Brazilian pepper populations (Schinus terebinthifolius Raddi). Twenty-two alleles in 223 individuals were identified from eight forest remnants located in the states of Minas Gerais, Espírito Santo, and Sergipe. All populations presented loci in Hardy-Weinberg
\end{abstract}


equilibrium deviation. Four populations presented six combinations of loci in linkage disequilibrium. Six exclusive alleles were detected in four populations. Analysis of molecular variance showed the absence of diversity between regions and that between the populations $\left(G_{\mathrm{ST}}\right)$ was $41 \%$. Genetic diversity was structured in seven clusters $(\Delta K 7)$. Brazilian pepper populations were not structured in a pattern of isolation by distance and present genetic bottleneck. The populations São Mateus, Canastra, Barbacena, and Ilha das Flores were identified as management units and may support conservation projects, ecological restoration and in implementation of management plans for Brazilian pepper in the State of Sergipe.

Key words: Schinus terebinthifolius; Genetic diversity; Extraction; Fragmentation; Microsatellites; Exclusive alleles

\section{INTRODUCTION}

The conservation of habitats and species, which are facing the rapid degradation and fragmentation, is an urgent necessity for sustainability. To outline strategies for in situ and exsitu conservation of species, the knowledge about genetic diversity is an important tool aiming sustainable. Little-known information of the spatial genetic structure exists in most species that are being constantly explored, particularly their fruits and flowers (Volis et al., 2010).

Schinus terebinthifolius Raddi fruits are commercially known as Brazilian pepper, and are highly appreciated as a spice around the world. This information contributes for establishment of extractive activity in several regions, which set this species as endangered.

The extraction of Brazilian pepper fruits is a cause of great concern because it results in the absence of seeds on soil, restricting its spatial and temporal distribution. It is important to address how Brazilian pepper is explored and which are the consequences of its extractivism. The riparian extractives' communities of Brazil sell the pepper fruits about $\mathrm{R} \$ 2.00$ per kilogram. The agro-factories market these fruits from riparian communities for $€ 80.00$ per kilogram in the international market. Although underprice is an amount earn by community which corresponds to $20 \%$ of the total budget of these extractivists. Aiming to reach and collect the fruits over trees several branches containing fruits are cracked without considering the need to preserve seeds for natural seed banks and for species sustainability in those habits. Research carried on technical, social, economic, and environmental aspects of extrativism and commercial exploration of this species highlighted the need for establishing the species management (Jesus and Gomes, 2013).

Using populations of Schinus sp from South America, Williams et al. (2002) developed simple sequence repeat (SSR) primers aiming to study the genetic diversity. However, there were no reports of specific extractivism in such areas. Otherwise, we report the details of the sampling in three states of Brazil in two different regions (northeast and southeast). Beyond this evidence, there is such difference in the type of exploration occurring in Florida in comparison which is done in Brazil, more specifically in Sergipe.

In another work Williams et al. (2005) studied chloroplast DNA and SSR regions of Schinus genome, and composed plant samples from Florida, Paraguay, Argentina, and Brazil (regions of Municipalities of Balneario Camburiú, Curitiba, Irati, and Palmital). 
In our present study, were studied SSR markers for Schinus populations from three very different edapho-climatic Brazilian states thereby, Minas Gerais (MG), Espírito Santo (ES) (wildlife refuge area near the Rio Doce basin), and Sergipe (São Francisco River Basin) (Carnaval and Moritz, 2008).

In both studies of Williams et al. $(2002,2005)$ there are reports of the diversity in Schinus population in Florida, based on a sampling of few matrices, where the species occurs naturally. However, populations from the southeast and northeast of Brazil were not included in such study. Additionally, unlike the last cited work (Williams et al., 2005) our main objective was to identify the areas with high genetic diversity of Schinus for seed collection and for future use in conservation, and furthermore to explain the distribution of seeds in the course of the São Francisco River and adjacent land as areas connecting the populations of Minas Gerais, Espírito Santo, and Sergipe.

Considering the need for species management and conservation, the aim of the present study was to quantify the genetic diversity of S. terebinthifolius in several forest remnants. The knowledge about the genetic diversity of the studied populations should contribute to identify the management units for conservation of the species diversity in the Lower São Francisco

River Basin. Moreover, some strategies should be established for sustainable management of Brazilian pepper, mainly in the State of Sergipe, where extractivism and degradation of forest remnants is relevant.

Hybridization is used in crop breeding to obtain segregant populations with interesting agronomic traits and broad genetic variability. This method combines the available genes from two or more different genitors resulting in a unique individual (Allard, 1999).

The choice of SSR molecular markers is justified because they are powerful tools for analyzing the genome diversity within a species, and for examining the genetic relationships between individuals and populations. This study is the foundation for breeding studies aimed at establishing planted areas. For analysis of plant genetics microsatellites or SSRs have been used the genetic diversity, population structure, and other studies (Tautz 1989; GonçalvesVidigal and Rubiano, 2011).

\section{MATERIAL AND METHODS}

\section{Areas sampling and characterization}

Leaf samples of 223 Brazilian pepper plants in reproductive stage were collected from eight natural populations in the states of Espírito Santo, Minas Gerais, both in Southeast and Sergipe in the Northeast region of Brazil (Table 1).

\section{Genomic DNA extraction}

Leaf samples were ground using PVP (polyvinylpyrrolidone) and $1000 \mu \mathrm{L}$ CTAB (Hexadecyltrimethylammonium bromide) in 2\% extraction buffer (100 mM Tris, $\mathrm{pH} \mathrm{8.0;50}$ mM EDTA, pH 8.0; $500 \mathrm{mM} \mathrm{NaCl}$; Doyle and Doyle, 1987).

Polymerase chain reaction (PCR) was performed in a total volume of $16.5 \mu \mathrm{L}$, which contained $3 \mu \mathrm{L}$ DNA added to $13.5 \mu \mathrm{L}$ reaction mix (3.0 $\mu \mathrm{L}$ 10X PCR buffer, $1.5 \mu \mathrm{L} 2.5 \mathrm{mM}$ dNTPs, $0.2 \mu \mathrm{L} 5 \mathrm{U} / \mu \mathrm{L}$ Taq polymerase, $0.75 \mu \mathrm{L} 2 \mu \mathrm{M}$ each primer, and ultrapure water q.s. to make). 
Table 1. Area sampling and characterization of the Shinus terebinthifolius populations located in the states of Minas Gerais: CN (Canastra), LV (Lavras), BA (Barbacena); Espírito Santo: SM (São Mateus); Sergipe: PR (Propriá), NE (Neópolis), IF (Ilha das Flores), and CA (Carmópolis).

\begin{tabular}{|c|c|c|c|c|c|c|c|c|}
\hline 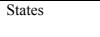 & \begin{tabular}{|l} 
Localization \\
\end{tabular} & \begin{tabular}{|l|}
$\begin{array}{c}\text { Sampling } \\
\text { (individuals) }\end{array}$ \\
\end{tabular} & $\begin{array}{l}\text { Geographic } \\
\text { coordinates }\end{array}$ & $\begin{array}{l}\begin{array}{l}\text { Climate } \\
\text { (Köppen-Geiger) }\end{array}\end{array}$ & \begin{tabular}{|c|}
$\begin{array}{c}\text { Average annual } \\
\text { rainfall }(\mathrm{mm})\end{array}$ \\
\end{tabular} & \begin{tabular}{|c|}
$\begin{array}{c}\text { Elevation } \\
(\mathrm{m})\end{array}$ \\
\end{tabular} & Vegetation & Characterization \\
\hline \multirow[t]{3}{*}{ Minas Gerais } & Canastra (CN) & 27 & $\begin{array}{l}20^{\circ} 18^{\prime} 50.64^{\prime \prime S} \\
46^{\circ} 18 ' 38.07 " \mathrm{~W}\end{array}$ & $\begin{array}{l}\text { Warm temperate climate } \\
\text { with dry winter (Cwb) }\end{array}$ & 1484 & 781 & Riparian forest & $\begin{array}{l}\text { - Riparian vegetation corridor interrupted by } \\
\text { highway; } \\
\text { - Low density of woody vegetation area }\end{array}$ \\
\hline & \begin{tabular}{|l|} 
Lavras (LV) \\
\end{tabular} & 12 & $\begin{array}{l}21^{\circ} 14^{\prime} 43.77^{\prime \prime S} \\
44^{\circ} 59^{\prime} 30.53^{\prime \prime} \mathrm{W}\end{array}$ & $\begin{array}{l}\text { Warm temperate climate } \\
\text { with dry winter (Cwb) }\end{array}$ & 1492 & 870 & $\begin{array}{l}\text { Semideciduous } \\
\text { forest }\end{array}$ & $\begin{array}{l}\text { - Distance between individuals about } 3 \mathrm{~m} \text {; } \\
\text { - Low species richness; } \\
\text { - Buildind area }\end{array}$ \\
\hline & Barbacena (BA) & 30 & $\begin{array}{l}21^{\circ} 15^{\prime} 02.73^{\prime \prime} \mathrm{S} \\
43^{\circ} 45^{\prime} 27.37^{\prime \prime} \mathrm{W}\end{array}$ & $\begin{array}{l}\text { Warm temperate climate } \\
\text { with dry winter }(\mathrm{Cwb})\end{array}$ & 1519 & 1100 & $\begin{array}{l}\text { Semideciduous } \\
\text { forest }\end{array}$ & $\begin{array}{l}\text { - Species richness; } \\
\text { - High density }\end{array}$ \\
\hline Espíito Santo & São Mateus (SM) & 32 & $\begin{array}{l}18^{\circ} 466^{3} 36.311^{\prime \prime S} \\
39^{\circ} 48^{\prime} 43.71 " \mathrm{~W}\end{array}$ & $\begin{array}{l}\text { Equatorial savannah } \\
\text { with dry winter (Aw) }\end{array}$ & 1432 & 15 & Atlantic forest & $\begin{array}{l}\text { - Distributed along the road; } \\
\text { - Shrubby vegetation and dominance of juveniles; } \\
\text { - High extraction of fruit of the Brazilian pepper }\end{array}$ \\
\hline \multirow[t]{4}{*}{ Sergipe } & Propriá (PR) & 30 & $\begin{array}{l}10^{\circ} 13^{\prime} 19.67^{\prime \prime S} \\
36^{\circ} 47^{\prime} 35.45 " \mathrm{~W}\end{array}$ & $\begin{array}{l}\text { Equatorial savannah } \\
\text { with dry summer (As) }\end{array}$ & 806.1 & 10 & $\begin{array}{l}\text { Atlantic forest with } \\
\text { associations of the } \\
\text { savanna }\end{array}$ & $\begin{array}{l}\text { - Fragmented islands; } \\
\text {-High extraction of the Brazilian pepper; } \\
\text { - Presence of pastures and people flow; } \\
\text { - Low density of individuals }\end{array}$ \\
\hline & \begin{tabular}{|l} 
Neópolis (NE) \\
\end{tabular} & 30 & $\begin{array}{l}10^{\circ} 17^{\prime} 45.02^{\prime \prime S} \\
36^{\circ} 35^{\prime} 42.93^{\prime \prime} \mathrm{W}\end{array}$ & $\begin{array}{l}\text { Equatorial savannah } \\
\text { with dry summer (As) }\end{array}$ & 1200 & 11 & $\begin{array}{l}\text { Atlantic forest with } \\
\text { associations of the } \\
\text { savanna }\end{array}$ & $\begin{array}{l}\text { - Brazilian pepper collection on the banks of the } \\
\text { São Francisco river and islands; } \\
\text { - High activity of extraction; } \\
\text { - Presence of pastures, agriculture and buildings; } \\
\text { - The area has clay extraction and fuelwood and } \\
\text { stakes }\end{array}$ \\
\hline & \begin{tabular}{|l|} 
Ilha das Flores (IF) \\
\end{tabular} & 47 & $\begin{array}{l}10^{\circ} 25^{\prime} 58.63^{\prime \prime} \mathrm{S} \\
36^{\circ} 26^{\prime} 09.38^{\prime \prime} \mathrm{W}\end{array}$ & $\begin{array}{l}\text { Equatorial savannah } \\
\text { with dry summer (As) }\end{array}$ & 1200 & 10 & $\begin{array}{l}\text { Atlantic forest with } \\
\text { associations of the } \\
\text { Sandbank and Mangroves }\end{array}$ & - Presence of pastures and flooded areas \\
\hline & Carmópolis (CM) & 12 & $\begin{array}{l}10^{\circ} 38^{\prime} 46.76^{\prime \prime S} \\
36^{\circ} 56^{\prime} 53.977^{\prime \prime} \mathrm{W}\end{array}$ & $\begin{array}{l}\text { Equatorial savannah } \\
\text { with dry summer (As) }\end{array}$ & 1400 & 11 & Atlantic forest & $\begin{array}{l}\text { - Controlled access of persons; } \\
\text { - High density; } \\
\text { - Vegetation fragmented with oil prospection }\end{array}$ \\
\hline
\end{tabular}

A set of eight microsatellite primers developed for Brazilian pepper (Williams et al., 2002) was used for all the samples. DNA amplification was carried out in the thermocycler, GeneAmp PCR System 9700. The cycling conditions were as follows: an initial denaturation step at $92^{\circ} \mathrm{C}$ for $60 \mathrm{~s}$, followed by 31 cycles consisting of a $5 \mathrm{~s}$ denaturation step at $92^{\circ} \mathrm{C}, 5 \mathrm{~s}$ annealing at a temperature specific for each primer (Williams et al., 2002), and an extension step of $10 \mathrm{~s}$ at $72^{\circ} \mathrm{C}$.

The amplified products were separated on $3 \%$ high resolution agarose gels (MetaPhor ${ }^{\circledR}$ FMC BioProducts, Rockland, ME, USA) for $3 \mathrm{~h}$, and stained with ethidium bromide. To determine the size of the amplified products were used 20 and $50 \mathrm{bp}$ leader.

\section{Statistical analysis}

Genotyping was performed using the Micro Checker version 2.2.3 software (Van Oosterhout et al., 2004). The frequency of null alleles at each locus was estimated using the Brookfield \# 1: $\mathrm{r}=\left(\mathrm{H}-H_{\mathrm{O}}\right) /\left(1+H_{\mathrm{E}}\right)$ estimator. The corrected allele frequencies were later used for the analysis of genetic diversity.

Genetic diversity was characterized using the Genetic Data Analysis (GDA) software (Lewis and Zaykin, 2002) from the following parameters: allelic richness or mean number of allele per locus $\left(N_{\mathrm{A}}\right)$, number of effective allele per locus $\left(N_{\mathrm{E}}\right)$ and observed $\left(H_{\mathrm{O}}\right)$ and expected heterozygosity according to the expectations of the Hardy-Weinberg Equilibrium $\left(H_{\mathrm{E}}\right)$. Adherence of phenotypic frequencies to the proportions of expected genotype by the Hardy-Weinberg equilibrium was tested by the Fisher's exact test.

The genetic distance between the populations was characterized by hierarchical analysis of variance of the allelic frequencies, as described by Weir and Cockerham (1984). Estimatives of mean fixation index within populations $\left(F_{\text {IS }}\right)$, total fixation index for all populations $(F)$, and divergence among populations $\left(\mathrm{q}_{\mathrm{p}}\right)$ were calculated using the GDA software (Lewis and Zaykin, 2002). The 95\% confidence interval of these estimatives were obtained by 10,000 loci resamplings. 
The genetic diversity of individuals among and within the populations was evaluated by analysis of molecular variance (AMOVA), using the GenAlEx software (Peakall and Smouse, 2006). It was calculated as $R_{S T}$ for all populations and between pairs of populations (Peakall and Smouse, 2006). Significance of the estimative was obtained by using 1,000 permutations, and confidence interval at $95 \%$, by 10,000 resamplings. Principal Coordinates Analysis (PCoA) for identification of the genetic diversity patterns was carried out using the GenAlEx software (Peakall and Smouse, 2006). Genetic differentiation $\left(G_{\mathrm{ST}}\right)$ among the populations was also estimated according to the method of Hedrick (2005) using the GDA_NT software (Degen, 2006).

The Mantel test was used to evaluate whether there was a positive correlation between the matrix of genetic differentiation between the pairs of populations $\left(R_{\mathrm{ST}}\right)$ and the spatial distance matrix between the populations, using the NTSYS-pc 2.0 software (Rohlf, 2001).

To verify whether Brazilian pepper populations have undergone a recent reduction in genetic diversity, the BOTTLENECK Version 1.2.02 software (Cornuet and Luikart, 1996) used was the following mutation models: Infinite Alleles Model (IAM), Single Mutation Model (SMM), and Two-phase Mutation model (TPM). The significance of the genetic diversity excess $\left(H_{\mathrm{E}}>\mathrm{Heq}\right)$ was evaluated using the Wilcoxon test, because it is more consistent when used for less than 20 loci (Piry et al., 1999), based on 10,000 replications.

Analysis of population genetic structure was carried out based on the Bayesian clustering method with the aid of STRUCTURE v. 2.3.3 software (Hubisz et al., 2009). The individuals probabilistically clustered according to their genotypes in $\mathrm{K}$ populations. The set of parameters undertook the "admixture" model with correlated allele frequency, and simulations were carried out in burn-in of 100,000 replications, with $\mathrm{K}$ values ranging from 2 to 10 clusters. The number of clusters $(\Delta \mathrm{K})$ was determined in accordance with the Structure Harvester software (Earl and Vonholdt, 2012).

\section{RESULTS}

Null alleles were detected in São Mateus (SM), Ilha das Flores (IF), Neópolis (NE), and Carmópolis (CA) populations. However, after correction (Excluding Null Alleles - ENA), the null alleles did not affect the results, showing that the possible deviations on HardyWeinberg equilibrium (EHW) in these populations did not influence the analysis (Martins et al., 2008).

BA, NE, and CA populations were the ones with the lowest number of alleles per loci $(A=1.71)$; CN presented the highest allelic richness (2.42).

In the genetic diversity analysis, which was carried out separately for each population, it was verified the heterozygosity $\left(H_{\mathrm{E}}\right)$ decreased in the populations PR and BA $(0.20), \mathrm{LV}, \mathrm{NE}$, and IF (0.28), whereas it increased in the populations SM (0.41), CN (0.38), and CA (0.36). High endogamy coefficient $(f)$, ranging from -0.393 to 0.535 , was also observed; only SM and IF had lower endogamy coefficient ( 0.1 and 0.15 , respectively; Table 2$)$.

Data obtained from the analysis of significant deviations in mutation-drift equilibrium in the models (IAM, TPM, and SMM) evidenced the presence of genetic bottleneck in LV, IF, and CA (Table 3). 
Table 2. Estimate of number of individuals $(\mathrm{N})$, number of alleles per locus $(A)$,observed heterozygosity $\left(H_{\mathrm{O}}\right)$, genetic diversity $\left(H_{\mathrm{E}}\right)$, maximum diversity $\left(h_{\max }\right)$, and fixation index $(f)$ of Shinus terebinthifolius populations (Pop) located in the states of Minas Gerais: CN (Canastra), LV (Lavras), and BA (Barbacena); Espírito Santo: SM (São Mateus); and Sergipe: PR (Propriá), NE (Neópolis), IF (Ilha das Flores), and CA (Carmópolis).

\begin{tabular}{l|c|c|c|c|c|c|c}
\hline Pop & $\mathrm{N}$ & $A$ & $H_{\mathrm{O}}$ & $H_{\mathrm{E}}$ & $h_{\max }$ & $H_{\mathrm{O}} / h_{\max }$ & $f$ \\
\hline BA & 27.43 & 1.71 & 0.25 & 0.20 & 0.41 & $49.13 \%$ & -0.22 \\
\hline CN & 26.43 & 2.42 & 0.25 & 0.38 & 0.59 & $64.76 \%$ & 0.35 \\
\hline SM & 30.71 & 2.14 & 0.37 & 0.41 & 0.53 & $77.90 \%$ & 0.10 \\
\hline LV & 12.14 & 1.85 & 0.13 & 0.28 & 0.46 & $60.72 \%$ & 0.53 \\
\hline PR & 24.57 & 1.86 & 0.26 & 0.20 & 0.99 & $20.51 \%$ & -0.30 \\
\hline NE & 28.57 & 1.71 & 0.33 & 0.28 & 0.41 & $66.47 \%$ & -0.20 \\
\hline IF & 42.5 & 2.00 & 0.24 & 0.28 & 0.50 & $56.56 \%$ & 0.15 \\
\hline CA & 11.28 & 1.71 & 0.49 & 0.36 & 0.41 & $87.52 \%$ & -0.39 \\
\hline Total & 25.45 & 1.93 & 0.29 & 0.30 & 0.99 & $30.07 \%$ & 0.03 \\
\hline
\end{tabular}

Table 3. Bottleneck analysis (genetic bottleneck) carried out in Brazilian pepper populations (Schinus terebinthifolius Raddi) (P) located in the states of Minas Gerais: CN (Canastra), LV (Lavras), and BA (Barbacena); Espírito Santo: SM (São Mateus); and Sergipe: PR (Propriá), NE (Neópolis), IF (Ilha das Flores), and CA (Carmópolis).

\begin{tabular}{l|l|l|c|c|c|c|c|c|c|c|c}
\hline \multicolumn{2}{l|}{ Pop } & BA & CN & SM & LV & PR & IF & NE & CA \\
\hline \multirow{3}{*}{ Wilcoxon test } & IAM & P & 0.09 & 0.22 & 0.89 & $0.05^{*}$ & 0.11 & $0.03^{*}$ & 0.06 & $0.01^{*}$ \\
\cline { 2 - 27 } & SMM & P & 0.15 & 0.42 & 1.0 & $0.04^{*}$ & 0.31 & $0.03^{*}$ & 0.09 & $0.01^{*}$ \\
\cline { 2 - 12 } & TPM & P & 0.09 & 0.22 & 0.95 & $0.04^{*}$ & 0.31 & 0.06 & $0.01^{*}$ \\
\hline
\end{tabular}

P: Probability $<0.05$; significant heterozygosity excess detected by the Wilcoxon test; classification test according to the models IAM (infinite allele model), SMM (simple mutation model), and TPM (two-phase mutation model).

There was no genetic differentiation between southeast and northeast regions of Brazil. However, there are genetic differentiation among the populations (0.35). Genetic differentiation among the populations was statistically different from zero $\left(\mathrm{q}_{\mathrm{p}}=0.28\right.$, with confidence interval of 0.16 to 0.39 ), indicating that $28.6 \%$ of genetic diversity was among the populations. Using another estimative of genetic differentiation, values of $R_{S T}(=0.35)$ were higher $(\mathrm{P}>0.05)$ indicating $35 \%$ of the diversity was observed among the populations. Using $G_{\mathrm{ST}(\text { Hedrick })}$ estimative, the value obtained was also high (0.41), i.e., $59 \%$ of the genetic divergence was observed within the populations.

The dendrogram by the Unweighted Pair Group Method with Arithmetic Mean (UPGMA) method, based on genetic differentiation among the populations (Rst), revealed the greatest distance of IF from the other populations (Figure 1), and the formation of two clusters. The first cluster constituted by BA, CN, SM, NE, and CA, with higher similarity between $\mathrm{CN}$ and SM. The second cluster was formed by LV and PR. These results were confirmed by PCoA, which explained the $62.15 \%$ and $15.80 \%$ of genetic differentiation between the Brazilian pepper populations, where SM (ES), CN (MG), and NE (SE) had a tendency to form a discrete cluster (Figure 2).

The number of gene clusters generated by the Bayesian analysis with all the populations led us to infer that the best subdivision obtained corresponded to seven clusters $(\Delta \mathrm{K}=7$; Figure 3). BA (MG) had the highest number of individuals belonging to cluster $7(82 \%)$. The populations, CN (MG) and SM (ES), presented higher distribution of individuals in the clusters 3 (37 and 23\%, respectively) and 4 (37.8 and 45\%, respectively). All the populations 
from Sergipe (PR, IF, NE, and CA) and one population from Minas Gerais (LV) had higher representativeness (18-30\%) in clusters 1,2, and 6, which proved to be more homogeneous. Cluster 5 presented a high representativeness for IF (28\%), followed by LV (96\%), PR (5\%), NE (3\%), CA (2\%), SM (1.1\%), CN (1\%), and BA $(<1 \%)$.

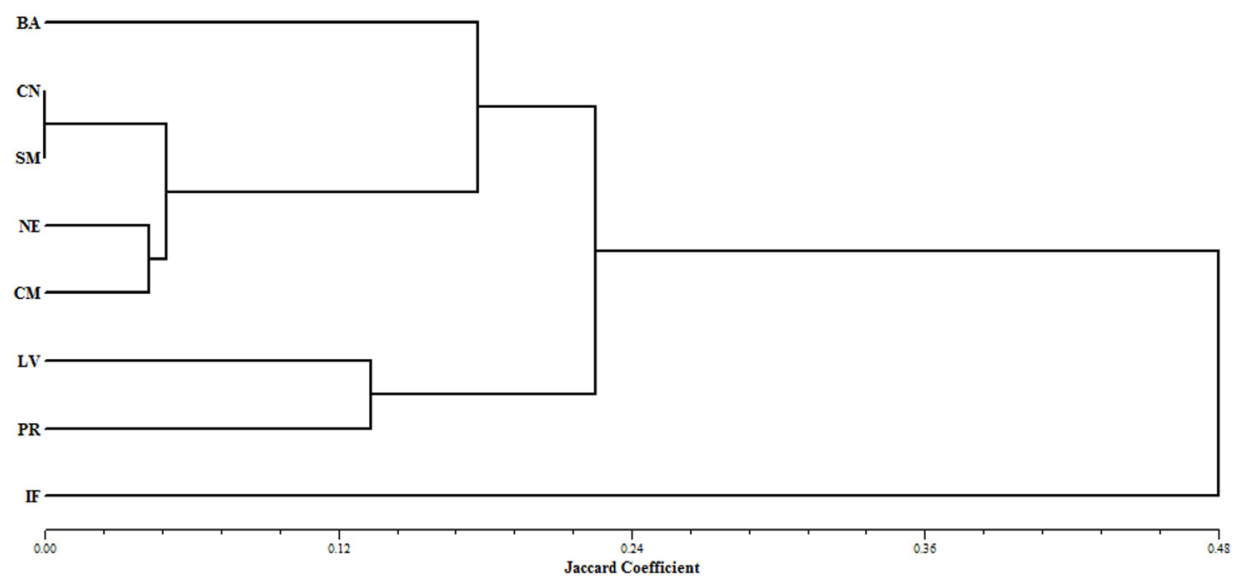

Figure 1. Clustering Dendrogram between pairs of Schinus terebinthifolius populations located in the states of Minas Gerais: CN (Canastra), LV (Lavras), and BA (Barbacena); Espírito Santo: SM (São Mateus); and Sergipe: PR (Propriá), NE (Neópolis), IF (Ilha das Flores), and CA (Carmópolis), according to the genetic distance of Nei (1978).

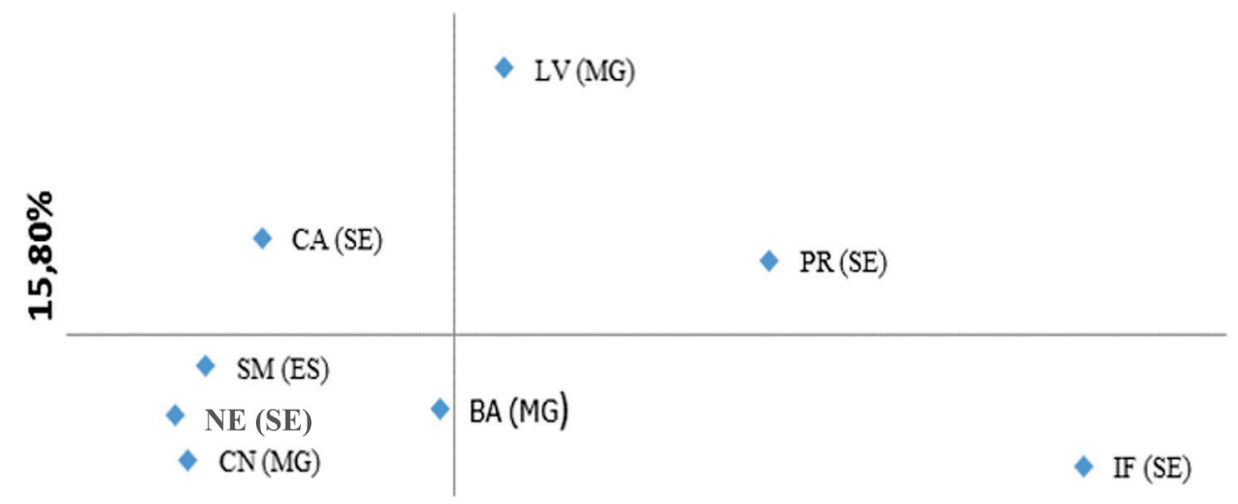

$62,15 \%$

Figure 2. Principal coordinates analysis of Schinus terebinthifolius populations in the states of Minas Gerais: CN (Canastra), LV (Lavras), and BA (Barbacena); Espírito Santo: SM (São Mateus); and Sergipe: PR (Propriá), NE (Neópolis), IF (Ilha das Flores), and CA (Carmópolis).

Based on the methodology described by Diniz-Filho and Telles (2002), the intercept on the $\mathrm{x}$-axis by Mantel correlation indicated should be a distance of $142 \mathrm{Km}$ for the definition of the management units (MUs). 


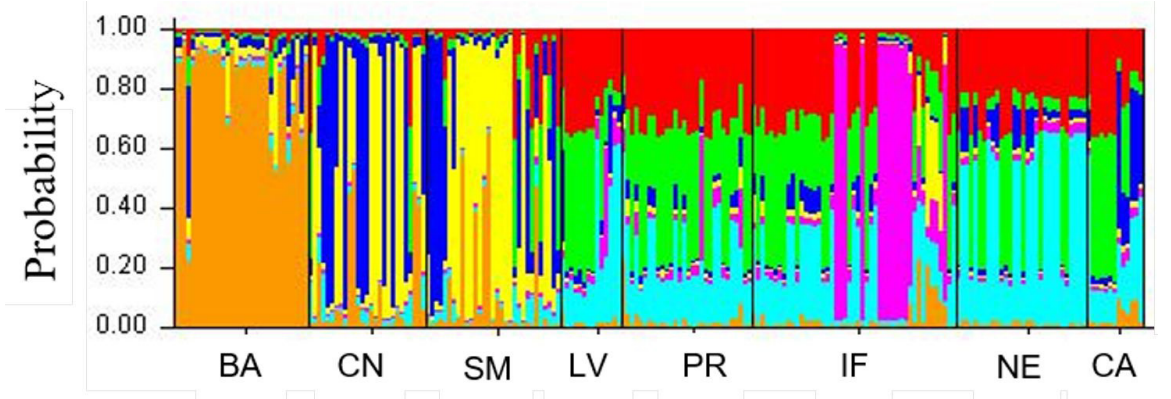

\section{Schinus terebinthifolius Raddi Populations}

Figure 3. Genetic structure of Schinus terebinthifolius populations in the states of Minas Gerais: CN (Canastra), LV (Lavras), and BA (Barbacena); Espírito Santo: SM (São Mateus); and Sergipe: PR (Propriá), NE (Neópolis), IF (Ilha das Flores), and CA (Carmópolis), obtained by the Bayesian analysis. The y-axis indicates the percentage of participation in each of the estimated K clusters.

\section{DISCUSSION}

Despite the CN population presenting higher allelic richness (2.42), this value was considerably lower than the values reported by Williams et al. (2005) in Brazilian pepper populations located in southern Brazil and Argentina (5-25 alleles per locus). The presence of a higher number of alleles indicated that the populations presented more diversity $(0.58)$ compared to the mean genetic diversity observed in the present study $\left(H_{\mathrm{E}}=0.30\right)$. This $H_{\mathrm{E}}$ value is considered low when compared to the values reported for the same species and for other tropical tree species using microsatellite markers. The study of Raposo et al. (2007) presented $H_{\mathrm{E}}$ of 0.60 in Carapa guianensis; Giudice-Neto et al. (2014) studied Machaerium villosum and found an $H_{\mathrm{E}}$ of 0.80; Silva et al. (2014) studied Hymenaea courbaril and detected an $H_{\mathrm{E}}$ of 0.71 for the Lábrea population, 0.72 for the Capixaba population, and 0.65 for the Porto Acre population.

Clearly, the genetic diversity values were different as they depended on intrinsic factors, such as crossing system and effective population size, and on extrinsic factors, such as number of individuals sampled, fragmentation, and isolation of the sampled areas, among others (Kramer et al., 2008).

To evaluate these differences, a study with the same species (S. terebinthifolius), from the south and southeast of Brazil (Irati, Curitiba, Camboriú, and Palmital) demonstrated higher genetic diversity $\left(H_{\mathrm{E}}=0.62\right.$; Williams et al., 2005) compared to that found in the present work $\left(H_{\mathrm{E}}=0.30\right)$, using the same set of microsatellite markers.

However, the observed heterozygosity in the study by Williams et al. (2005) was 0.39 , with significant heterozygote deficiency $(\hat{f}=0.37)$, although the populations presented high allelic richness (11.8 alleles). Although the Brazilian pepper populations studied in this work did not have high levels of genetic diversity, as described for other tropical tree species, they did not present endogamy $(\hat{f}=0.03)$ for the whole population set, indicating that they require actions for in situ conservation.

The extraction of Brazilian pepper fruits in Sergipe is a cause of concern because the communities, aiming to gather more fruits to sell to agro-factories, take out branches 
carrying fruits do not even consider the need to keep propagules for natural seed banks and the sustainability of species. The focus of the present study was to contribute to the multidisciplinary researches considering the technical, social, economic, and environmental aspects and to highlight the need for establishing the parameters for species management (Jesus and Gomes, 2013).

Williams et al. (2002) used the Schinus populations from South America in their study and developed the SSR primers. However, they did not report the specific area of collection, as we did in the present study, providing the details of the sampled regions. Apart from this difference, the exploration in Florida is not similar in Brazil, especially in Sergipe.

Williams et al. (2005) worked with chloroplast DNA and microsatellites, and used plant materials from Florida, Paraguay, Argentina, and Brazil (Balneario Camburiú, Curitiba, Irati, and Palmital).

Endogamy increase coefficient $(f)$ for each population when compared to the population indicates that, possibly, Brazilian pepper populations are undergoing genetic bottlenecks, probably due to the geographical isolation. Thus, the location of the populations must be considered, since some are found in landscapes, such as CN, BA and LV whereas other populations, besides facing natural barriers, rivers and mountainous elevations, occur in modified environments (ES and SE) with high exploitation of vegetation (Jesus and Gomes, 2013; Álvares-Carvalho et al., 2015). Other populations occur in environments with high degradation, such as SM, PR, NE, CA, and IF. Negative results of fragmentation on the genetic diversity of populations were found by Conson et al. (2013); these authors concluded the fragmentation of the Atlantic Forest biome, derived from recurring cycles of cuttings and burns, might be considered the main factor responsible for the reduction of heterozygosity in Luehea divaricata (Malvaceae).

The occurrence of linkage disequilibrium in the CN, SM, IF, and NE populations indicated the presence of non-random associations between polymorphisms, since high values of $(f)$ (endogamy) are responsible for keeping the disequilibrium in the population (Futuyma, 2005). According to Williams et al. (2005), the presence of linkage disequilibrium suggests that the populations are isolated, which favors endogamy in the population. This corroborates with the results obtained in the analysis of significant deviations in mutation-drift equilibrium, and evidences the presence of recent genetic bottleneck in LV, IF, and CA. Although moderate levels of genetic diversity were observed, these populations appeared to be in genetic drift. Thereby, the next generation might present a decrease in genetic diversity, since the effects of inbred crosses are observed immediately after a disturbance, and the decrease in genetic diversity occurs slowly over successive generations (Kramer et al., 2008). Da Silva et al. (2012) studying Luehea divaricata, which is a species with lifetime of 60 years, inferred that after 100 years, if measures for the recovery of the populations studied are not taken, a drastic reduction in genetic variability would be observed. However, in the case of Brazilian pepper, which is pioneer species ecological groups, with life cycles of 10-15 years (Maciel et al., 2003), decrease in genetic variability has already happened, and probably in just 10 years from now, sharp negative ecological responses of these disorders will be confirmed.

There was a high level of genetic differentiation $\left(\mathrm{F}_{\mathrm{ST}}=0.35\right)$, since the levels of genetic differentiation for tree species are described to range from 0.22 to 0.366 (Nybom, 2004). According to the author, these values are due to the pollination carried out by small insects and the species dispersion, mainly by birds, presenting a pattern of isolation by distance. 
However, Brazilian pepper populations presented a different pattern of isolation by distance because, as indicated by the Mantel test, there was no significant correlation between the genetic differentiation values and geographical distances. This suggests that Brazilian pepper populations are not structured in an isolation pattern by distance, as negative correlations indicate the absence of gene flow. Thus, the levels of genetic differentiation between the populations originate from factors other than spatial distance.

The superiority of the estimative obtained for genetic differentiation between the populations by the method of Hedrick (2005) is due to the peculiarities of the method, which considers the frequency and the type of (rare) alleles present in the populations. Thus, the high genetic differentiation between the Brazilian pepper populations can be explained by the presence of exclusive alleles present in the populations BA, CN, MS, and IF. In genetic differentiation analysis between two Carapa guianensis Aubl populations, moderate genetic diversity value was observed between the populations. The authors justified this diversity value $\left(\mathrm{R}_{\mathrm{ST}}=0.093\right)$ as result of the presence of exclusive alleles with relatively high frequency in both the populations (Raposo et al., 2007). Moura et al. (2011) address significant genetic differentiation in Solanum lycocarpum populations with five nuclear microsatellite markers $\left(\mathrm{G}_{\mathrm{ST}}=0,147\right)$ and obtained an estimative of historic gene flow of 0.36 , which is considered low $(\mathrm{Nm}<1)$. This value was approximated to that found in the present study with the same estimative. The number of migrants per generation was 0.49 . Therefore, due to the significant values of genetic divergence between the populations, it is possible to suggest the occurrence of genetic drift into each population, by the absence of gene flow, and due to stochastic processes that caused random modification of allele frequencies in each population over the time.

The principal coordinate shows the populations MS (ES), CN (MG), and NE (SE) which tend to form a discreet cluster. There are common alleles distributed among the regions (states). Another relevant fact in Brazilian pepper populations is the presence in IF population of higher genetic distance in relation to the other populations from Sergipe (Table 4).

Table 4. Genetic differentiation matrix for Schinus terebinthifolius Raddi after correction of null alleles (below the diagonal) and spatial distances $(\mathrm{km})$ between pairs of populations (above the diagonal) in the states of Minas Gerais: CN (Canastra), LV (Lavras), and BA (Barbacena); Espírito Santo: SM (São Mateus); and Sergipe: PR (Propriá), NE (Neópolis), IF (Ilha das Flores), and CA (Carmópolis).

\begin{tabular}{l|c|c|c|c|c|c|c|c}
\hline & BA & CN & SM & LV & PR & IF & NE & CA \\
\hline BA & - & 285 & 495 & 128 & 1.430 & 1.430 & 1.434 & 1.381 \\
\hline CN & 0.161 & - & 703 & 171 & 1.513 & 1.522 & 1.521 & 1.466 \\
\hline SM & 0.201 & $0.243^{*}$ & - & 607 & 1.001 & 992 & 1.000 & 951 \\
\hline LV & 0.141 & 0.004 & 0.155 & - & 1.503 & 1.509 & 1.507 & 1.455 \\
\hline PR & 0.204 & 0.306 & 0.273 & 0.136 & - & 61 & 23 & 10 \\
\hline IF & 0.450 & 0.597 & 0.562 & 0.412 & 0.182 & - & 23 & 61 \\
\hline NE & 0.223 & 0.067 & 0.049 & 0.243 & 0.333 & 0.613 & - & 55 \\
\hline CA & 0.190 & 0.080 & $0.017^{*}$ & 0.081 & 0.226 & 0.533 & 0.046 & - \\
\hline
\end{tabular}

*Not significant Rst $(\mathrm{P}>0.05)$.

Similar results were found by Costa et al. (2011) using 55 individuals from mangaba (Hancornia speciosa Gomes) from 11 locations of natural occurrence in the states of Bahia, Pará, Paraíba, and Sergipe. The authors reported strong genetic relatedness between individuals from the states of Paraiba, Sergipe, and Pará, when compared to individuals from the same state. These results support the findings of the Mantel test, in which the correlations between the genetic and geographical distances were negative and were not significant. It should be 
mentioned that LV population, located in the southeast of the country, presented genetic similarity with populations from Sergipe, located in the northeast, and they are $1,500 \mathrm{~km}$ apart. The number of gene clusters generated by the Bayesian analysis with all the populations led us to infer that the best subdivision obtained corresponded to seven clusters $(\Delta \mathrm{K}=7)$, with some mixtures observed in all the populations. In the study carried out with Luehea divaricata (Malvaceae), from nine remnants of the Atlantic Forest, with a mean of 29.8 individuals sampled in each population, the Bayesian analysis also presented seven clusters $(K=7)$ with high individual mixing among the clusters (Conson et al., 2013). The authors report that the different rates of migrants found confirm that not all the studied populations are isolated, and that the movement of alleles might result from the presence of isolated individuals left between some fragments that would work as trampoline for gene flow. Brazilian pepper populations, despite presenting similar results, have genetic discontinuities along their distribution and low gene flow, which provides evidences that these populations were connected in the past, but they got isolated over time. Although most $S$. terebinthifolius populations located in the Atlantic Forest fragments presented moderate levels of genetic diversity, the viability of these populations will be seriously endangered, and will result in loss of genetic variability, with inbreeding and genetic drift, if no actions are taken.

However, four management units were evidenced: two MUs were defined for the populations $\mathrm{CN}$ and $\mathrm{SM}$, one for the populations $\mathrm{LV}$ and $\mathrm{BA}$, and one for the populations PR, IF, and NE.

Taking into account the maintenance of the seven genetic clusters $(\Delta \mathrm{K}=7)$, the populations BA, MS, and IF are essential for the conservation of species due to significant representation of the genetic clustering. However, when other genetic characteristics are assigned, BA, SM, IF, and CN present exclusive alleles whereas low allele fixation index is observed in SM and IF. This highlights the importance of managing these populations to ensure the maintenance of the seven genetic clusters.

Knowledge of the genetic variability may contribute to the development of a proper management system focused on increasing and supplementing the native forests. We recommend the establishment of strategic planning for seedling growing and for seed bank establishment, to provide an exchange of alleles among individuals in the same area.

This combination permits an increase in population size and composition of different genotypes, aimed at the recovery of degraded environments, thereby, promoting a better future sustainability of the populations and the reappearance of fauna. Furthermore, we propose the development of further studies within these populations, to clarify the events involving the degradation process and genetic structure (Melo et al., 2015).

The results obtained in the present study revealed that the Schinus populations have low genetic diversity. The BA, SM, IF, and CN populations were determined to be the MUs, which may support conservation projects, restoration of degraded areas, and implementation of management plan for Brazilian pepper. Furthermore, IF (Ilha das Flores/SE) was determined to be a significant population for the management of the species in the states of Sergipe, Minas Gerais, and Espírito Santo.

\section{Conflicts of interest}

The authors declare no conflict of interest. 


\title{
ACKNOWLEDGMENTS
}

\author{
Research supported by CAPES and CNPq.
}

\section{REFERENCES}

Allard RW (1999). Principles of plant breeding. 2nd edn. J. Wiley \& Sons, New York.

Álvares-Carvalho SV, Duarte JF, Carvalho D, Pereira GS, et al. (2015). Schinus terebinthifolius: Population structure and implications. Biochem. Syst. Ecol. 58: 120-125. http://dx.doi.org/10.1016/j.bse.2014.10.002

Carnaval AC and Moritz C (2008). Historical climate modeling predicts patterns of current biodiversity in the Brazilian Atlantic forest. J. Biogeogr. 35: 1187-1201. http://dx.doi.org/10.1111/j.1365-2699.2007.01870.x

Conson AR, Ruas EA, Vieira BG, Rodrigues LA, et al. (2013). Genetic structure of the Atlantic Rainforest tree species Luehea divaricata (Malvaceae). Genetica 141: 205-215. http://dx.doi.org/10.1007/s10709-013-9719-4

Cornuet JM and Luikart G (1996). Description and power analysis of two tests for detecting recent population bottlenecks from allele frequency data. Genetics 144: 2001-2014.

Costa TS, da Silva AVC, Lédo AS, Santos ARF, et al. (2011). Diversidade genética de acessos do banco de germoplasma de mangaba em Sergipe. Pesquisa Agropecu. Bras. 46: 499-508. http://dx.doi.org/10.1590/S0100-204X2011000500007

Da Silva DCG, De Carvalho MCCG, Medri C, Medri ME, et al. (2012). Genetic structure and diversity of Brazilian tree species from forest fragments and riparian woods. In: Genetic diversity in plants (Çalişkan M, ed.). Tech Open Sci., Croacia, 319-412.

Degen B (2006). GDA_NT 2006. Genetic data analysis and numerical tests. Grosshansdorf, Institute for Forest Genetics, Version 2.

Diniz-Filho JAF and Telles MPC (2002). Spatial autocorrelation analysis and the identification of operational units for conservation in continuous populations. Conserv. Biol. 16: 924-935. http://dx.doi.org/10.1046/j.15231739.2002.00295.x

Doyle JJ and Doyle JL (1987). A rapid DNA isolation procedure for small quantities of fresh leaf tissue. Phytochem. Bull. 19: $11-15$.

Earl DA and Vonholdt BM (2012). STRUCTURE HARVESTER: a website and program for visualizing STRUCTURE output and implementing the Evanno method. Conserv. Genet. Resour. 4: 359-361. http://dx.doi.org/10.1007/ $\underline{\text { s12686-011-9548-7 }}$

Futuyma DJ (2005). Evolution Sinauer Associates, Sunderland.

Giudice-Neto J, Ramos RF, Moraes EM, Silva MJ, et al. (2014). Isolation and characterization of ten new microsatellite markers in Machaerium villosum Vogel (Fabaceae). Hoehnea 41: 77-80. http://dx.doi.org/10.1590/S2236$\underline{89062014000100007}$

Gonçalves-Vidigal MC and Rubiano LB (2011). Development and application of microsatellites in plant breeding. Crop Breed. Appl. Biotechnol. 11: 66-72. http://dx.doi.org/10.1590/S1984-70332011000500010

Hedrick PWA (2005). A standardized genetic differentiation measure. Evolution 59: 1633-1638. http://dx.doi. org/10.1111/j.0014-3820.2005.tb01814.x

Hubisz MJ, Falush D, Stephens M and Pritchard JK (2009). Inferring weak population structure with the assistance of sample group information. Mol. Ecol. Resour. 9: 1322-1332. http://dx.doi.org/10.1111/j.1755-0998.2009.02591.x

Jesus NB and Gomes LJ (2013). Importância socioeconômica. In: Pensando a biodiversidade: aroeira (Schinus terebinthifolius Raddi) (Gomes LJ, Silva-Mann R, Mattos PP and Rabbani ARC), São Cristóvão, 37-53.

Kramer AT, Ison JL, Ashley MV and Howe HF (2008). The paradox of forest fragmentation genetics. Conserv. Biol. 22: 878-885. http://dx.doi.org/10.1111/j.1523-1739.2008.00944.x

Lewis PO and Zaykin D (2002). GDA - Genetic Data Analysis: version 1.1 for Windows 95/NT.

Maciel MNM, Watzlawick LF, Schoeninger ER and Yamaji FM (2003). Classificação Ecológica das Espécies Arbóreas. Rev. Acad., Ciênc. Agrár. Ambient 1: 69-78.

Martins K, Santos JD, Gaiotto FA, Moreno MA, et al. (2008). Estrutura genética populacional de Copaifera langsdorffii Desf. (Leguminosae - Caesalpinioideae) em fragmentos florestais no Pontal do Paranapanema, SP, Brasil. Rev. Bras. Bot. Braz. J. Bot. 31: 61-69. http://dx.doi.org/10.1590/S0100-84042008000100007

Melo MFV, Gonçalves LO, Rabbani ARC, Álvares-Carvalho SV, et al. (2015). Populations of Erythrina velutina Willd. at risk of extinction. Genet. Mol. Res. 14: 10298-10307. http://dx.doi.org/10.4238/2015.August.28.15

Moura TM, Sebbenn AM, Martins K, Moreno MA, et al. (2011). Allelic diversity in populations of Solanum lycocarpum A. St.-Hil (Solanaceae) in a protected area and a disturbed environment. Acta Bot. Bras. 25: 937-940. http://dx.doi. 
org/10.1590/S0102-33062011000400023

Nybom H (2004). Comparison of different nuclear DNA markers for estimating intraspecific genetic diversity in plants. Mol. Ecol. 13: 1143-1155. http://dx.doi.org/10.1111/j.1365-294X.2004.02141.x

Peakall ROD and Smouse PE (2006). GenAlex 6: genetic analysis in Excel. Population genetic software for teaching and research. Mol. Ecol. Notes 6: 288-295. http://dx.doi.org/10.1111/j.1471-8286.2005.01155.x

Piry S, Luikart G and Cornuet JM (1999). BOTTLENECK: a computer program for detecting recent reductions in the effective population size using allele frequency data. J. Hered. 90: 502-503. http://dx.doi.org/10.1093/jhered/90.4.502

Raposo A, Martins K, Ciampi AY, Wadt LHO, et al. (2007). Diversidade genética de populações de andiroba no Baixo Acre. Pesquisa Agropecu. Bras. 42: 1291-1298. http://dx.doi.org/10.1590/S0100-204X2007000900011

Rohlf FJ (2001). Numerical taxonomy and multivariate analysis system. Version 2.1. New York: Exeter Software.

Silva SMM, Martins K, Mesquita AGG and Wadt LHO (2014). Parâmetros genéticos para a conservação de Hymenaea courbaril L. na Amazônia Sul-ocidental. Cienc. Florest. 24: 87-95. http://dx.doi.org/10.5902/1980509813326

Tautz D (1989). Hypervariability of simple sequences as a general source for polymorphic DNA markers. Nucleic Acids Res. 17: 6463-6471. http://dx.doi.org/10.1093/nar/17.16.6463

Van Oosterhout C, Hutchinson WF, Wills DPM and Shipley P (2004). MICRO-CHECKER: software for identifying and correcting genotyping errors in microsatellite data. Mol. Ecol. Notes 4: 535-538. http://dx.doi.org/10.1111/j.1471$\underline{8286.2004 .00684 . x}$

Volis S, Zaretsky M and Shulgina I (2010). Fine-scale spatial genetic structure in a predominantly selfing plant: role of seed and pollen dispersal. Heredity (Edinb) 105: 384-393. http://dx.doi.org/10.1038/hdy.2009.168

Weir BS and Cockerham CC (1984). Estimating F-statistics for the analysis of populations structure. Evolution 38: 13581370. http://dx.doi.org/10.2307/2408641

Williams DA, Overholt WA, Cuda JP and Hughes CR (2005). Chloroplast and microsatellite DNA diversities reveal the introduction history of Brazilian peppertree (Schinus terebinthifolius) in Florida. Mol. Ecol. 14: 3643-3656. http:// dx.doi.org/10.1111/j.1365-294X.2005.02666.x

Williams DA, Sternberg LDSL and Hughes CR (2002). Characterization of polymorphic microsatellite loci in the invasive Brazilian pepper, Schinus terebinthifolius. Mol. Ecol. Notes 2: 231-232. http://dx.doi.org/10.1046/j.1471$\underline{8286.2002 .00198 . \mathrm{x}}$ 